(1)

Acta Baltico-Slavica, 45

Warszawa 2021
Article No. 2587

DOI: $10.11649 /$ abs.2587

Citation: Miliūnaite, R. (2021). New lexis in the interaction of languages and cultures: The case of selfie in the Lithuanian language. Acta Baltico-Slavica, 45, Article 2587. https://doi.org/10.11649/ abs. 2587

\author{
Rita Miliūnaitè \\ Institute of the Lithuanian Language \\ Vilnius \\ rita.miliunaite@lki.lt \\ https://orcid.org/0000-0002-2292-1818
}

\title{
New Lexis in the Interaction of Languages and Cultures: The Case of Selfie in the Lithuanian Language
}

\section{Introduction}

The high-intensity interaction among languages and cultures amidst the landscape of globalisation noticeably affects the lexis of languages, with the amount of loanwords, translations from one language to another, and new coinages on the rise. This provides impetus for neological and neographical studies (cf. Fjeld \& Nygaard, 2012; Humbley, 2018, pp. 437-452; Kerremans, 2015; Mattiello, 2017). The Institute of the Lithuanian Language began observation and research of these processes back in 2011, at the time when the Database of Lithuanian Neologisms (hereafter DN), the databank of the latest Lithuanian lexis, was launched online (see Miliūnaite, 2018, pp. 1-21). It records lexical innovations that appear in modern usage and dissects their structural and functional properties, as well as investigates the reasons why some neologisms find a place in the system of the Lithuanian language while others are rejected by language users. 
The English word selfie ('a photograph that one has taken of oneself, esp. one taken with a smartphone or webcam and shared via social media') ${ }^{2}$ is one of the new loanwords that originated in the early twenty-first century and has since been quickly and broadly accepted all over the world. After it made its way into the Lithuanian language, it was quick to adapt to its grammatical system. Besides, as far as usage is concerned, it had to compete with its Lithuanian equivalents. The history of this word in the Lithuanian language followed a path that is quite typical of other similar new and popular loanwords, such as spamas (spam '(usually) unsolicited e-mail, junk mail') - Lith. brukalas; afterpartis (afterparty 'a party after an official event that takes place in an informal setting') - Lith. düzgés; influenceris, $-\dot{e}$ (influencer 'a celebrity, an opinion-shaper who is usually engaged in disseminating someone's ideas, especially in social networks and in the media') - Lith. itakdarys, - $\dot{e}$; vasabiai (Jap. wasabi 'a traditional green-coloured spicy Japanese condiment made from wasabi') - Lith. pipirkrieniai, and so on.

The history of the origin of the neologism selfie and the characteristics of its usage in the Lithuanian language make an interesting case. This English neologism and its Lithuanian equivalents can be considered a typical mini-model that showcases what happens when a loanword that denotes a new element of reality, which is trending and therefore has potential to spread, enters the Lithuanian language. This mini-model allows to analyse the following neological issues: (1) Who is the winner of the competition between borrowed and native means of expression, and why? (2) What is the reason behind some new words (borrowings and coinages) gaining prevalence while others sink into oblivion just after a few instances of usage? It is quite obvious that similar processes take place in the source languages of this word, which has set in motion the process of creation of remakes and equivalents in other languages as well.

The aim of this article is to investigate the history of the origin of the word selfie and to describe its usage in the Lithuanian language as well as its competition with its Lithuanian equivalents.

The objectives of this study are as follows:

(1) to present concise key information about the origins of the word selfie and its usage in the English language;

(2) to look into when and how the loanword selfie made its way into the Lithuanian language;

(3) to look into when the Lithuanian equivalents of the loanword selfie first appeared, and what kind of equivalents they were;

(4) to investigate the specific characteristics of how the loanword selfie and its Lithuanian equivalents function in usage and compete.

${ }^{1}$ selfie, selfy $<$ SELF $n .+-$ IE/-Y suffix (OED, n.d.).

${ }^{2}$ Unless specified otherwise, the meanings of neologisms are presented as sourced in the DN (n.d.). 
The study uses the descriptive-analytical and the comparative methods. Usage data have been taken from the Database of Lithuanian Neologisms and gathered online using the search engine Google and the online corpus WebCorp (WebCorp Linguist's Search Engine, n.d.).

\section{The word selfie in the English language and its spread to other languages}

\subsection{The advent of the selfie culture and the origin of the word}

The selfie culture can be considered a socio-psychological phenomenon of the twenty-first century, one that is closely connected to the proliferation of IT in general and social media (Facebook, Twitter, Instagram, Flickr, Snapchat, etc.) in particular (Eckel et al., 2018, pp. 1-2). The roots of this phenomenon can be found in the Japanese cuteness culture, kawaii, one of its trademarks being the public portrayal of oneself as a cute being, particularly in photos. Another factor contributing to the occurrence of selfie was the popularity of the purikura - Japanese photo booths where you can take a picture of yourself selecting a variety of visual effects and download the picture to your mobile phone (see Sandbye, 2018, pp. 305-326). ${ }^{3}$

The word selfie made its first appearance in September 2002 in Australian English (see MW, n.d.). The first known case of it being used in electronic communication occurred in an online forum, where a young man wrote about how he had tripped while climbing stairs and banged his lower lip. Having complained about how his lip would not heal, he took a picture of himself, uploaded it to the forum and apologised that his whole face was not visible, it being a selfie (Brumfield, 2013). This entry has been reposted multiple times:

Um, drunk at a mates 21 st, I tripped ofer [sic] and landed lip first (with front teeth coming a very close second) on a set of steps. I had a hole about $1 \mathrm{~cm}$ long right through my bottom lip. And sorry about the focus, it was a selfie.

Yet the word selfie had not been in any active use until 2012; it began to spread later, its popularity greatly boosted by celebrities taking selfies and uploading them on social media. Despite having been criticised as a potential cause of various psychological problems due to it promoting narcissistic behaviour and revealing personal information - and even considered to be synonymous to sexting ${ }^{4}$ (Coulthard,

${ }^{3}$ Self photography as a phenomenon first emerged with the invention of the camera, when people started experimenting with it. However, the advent of the selfie culture was conditional not only on social media but also on state-of-the-art smartphones with front-facing cameras.

${ }^{4}$ Sexting is exchange of erotic imagery (photos of oneself as often as not) in the electronic media, usually as text message or e-mails (DN, n.d.). 
2013) or viewed as life-threatening (when a person is trying to take a selfie under extreme conditions) - the selfie has come to stay in electronic communication. At the same time, this phenomenon has gone through a series of modifications that have brought forth a number of new words to name them.

\subsection{The socialisation and lexicalisation of the word selfie}

Every new word has a longer or shorter lifecycle. It becomes anchored among users in two phases: through socialisation (anchorage in society) and lexicalisation (anchorage in the language system) (cf. Hanaqtah, 2019, p. 160, according to Parianou \& Kelandrias, 2002, p. 756; Zabotkina, 1989, p. 7). In turn, the socialisation of a neologism can be further split into smaller stages:

(1) the initial spread of the neologism in a narrow language community (such as university professors and students, the media community, and so on); ${ }^{5}$

(2) the fixing of the neologism in public usage (articles, dissertations and other publications, social media, and so on);

(3) the proliferation of the neologism across the language community.

The second phase of the neologism's functioning - its lexicalisation - means that the new word is becoming anchored in the language system. In this regard, the following stages of this phase can be identified:

(1) the focused inclusion of the neologism that has potential for usage in dictionaries of neologisms;

(2) the final anchorage of the neologism in the language as evidenced by its inclusion in thesauri (this shows that the neologism is gradually losing its novelty tag).

However, this is basically only a theoretical model, because in practice the processes can vary significantly. For instance, when a neologism appears in social media, as was the case with the word selfie, it can skip a few stages of socialisation right away. The duration of these processes depends on linguistic and extra-linguistic circumstances. What matters is the popularity of the object denominated by the neologism (that is, the frequency of usage of the word as such), the acceptability of the form of the neologism, the semantic clarity, the authority figures who use it, and so on. Besides, in the era of digital databanks and online dictionaries, a neologism can make its way into inventories of neologisms even before the lexicalisation of the word takes place.

The word selfie can be said to have gone through all these stages in the English language and has become an integral part of the new digital culture and the language

5 New words that have just emerged and still have narrow application are sometimes referred to as protologisms. This word was forged in 2005 by Mikhail Epstein, a British professor of Russian descent (see MD-p, n.d.). 
that describes it. The publishers of Oxford Dictionaries have searched the corpus of modern English words with its nearly 150 million entries to determine that since 2012, the usage of selfie and the phenomenon as such have seen a surprising surge in popularity, which has skyrocketed by a staggering 17,000 per cent (Coulthard, 2013). As a result, in 2013 they named selfie the Word of the Year.

\subsection{The definitions of the word selfie}

The major dictionaries of the English language define selfie in much the same fashion:

selfie: A photograph that one has taken of oneself, esp. one taken with a smartphone or webcam and shared via social media. (OED, n.d.)

selfie: a photo that you take of yourself, usually for use in social media. (MD-s, n.d.)

selfie: an image that includes oneself (often with another person or as part of a group) and is taken by oneself using a digital camera especially for posting on social networks. (MW, n.d.)

These definitions point to the following key semantic elements of the word selfie:

(1) taking pictures of oneself (possibly including other persons and objects),

(2) taking pictures with a smartphone or webcam,

(3) posting your picture on social media.

Dictionaries that are developed by online communities contain a much larger number of definitions of selfie, which also display a much greater variety. As a case in point, the Urban Dictionary (UD, n.d.) offers more than 90 descriptions of selfie, including these ones:

The beginning of the end of intelligent civilization.

A strange phenomenon in which the photographer is also the subject of the photograph, in a subversive twist on the traditional understanding of the photograph. Usually conducted because the subject cannot locate a suitable photographer to take the photo, like a friend.

A picture taken of yourself that is planned to be uploaded to Facebook, Myspace or any other sort of social networking website. You can usually see the person's arm holding out the camera in which case you can clearly tell that this person does not have any friends to take pictures of them so they resort to Myspace to find internet friends and post pictures of themselves, taken by themselves. A selfie is usually accompanied by a kissy face or the individual looking in a direction that is not towards the camera.

Contrary to professional dictionaries, the definitions available in their amateur online counterparts often indicate a subjective perception of the object, yet they can 
hold some lexicographic value due to the shades of meaning and contexts of usage that are not typically present in lexicographic definitions.

\subsection{Remakes of selfie in the English language}

The fact that a neologism provides a foundation on which new words can be built is also indicative of how firmly anchored it is in the language system. The English language has a lot of remakes of the word selfie to tag the different types of this phenomenon (see "Belfie, drelfie, helfie, and more variations on selfie", 2015). ${ }^{6}$ They usually are made of the beginning of the word denoting the object in the picture and -(el)fie, which is the ending of selfie. This means that such names are made by way of blending, a method that is enjoying a high degree of popularity right now. For instance, helfie is a selfie of one's hair; belfie is a selfie of one's butt; shelfie is a selfie of a bookshelf (or a kitchen or bathroom shelf); drelfie is a selfie of one who is drunk, and so on. If, in addition to the person taking it, the picture also includes someone else, the selfie is called a wefie. Selfies of pets go under the name of petfie.

\subsection{The spread of selfie to other languages}

Since the word selfie is connected to a certain stereotypical behaviour in electronic communication in the context of globalisation and mediatisation (see Hjarvard, 2013, pp. 137-150), it has started spreading, quite naturally, in social media along with the whole culture of selfie, and has been accepted in other languages as a sign of that culture.

If we were to search for this word in the multilingual wordnet at BabelNet.org, which covers 50 languages, we would discover a long list of languages in which it is used. An extract from the search results (Fig. 1) shows that in some languages selfie is now facing some competition from equivalents made using the means of expression of the host language.

For instance, in addition to the loanword selfie (or its adaptations), the Catalonian language has autofoto; the Dutch - otofoto; the Finnish - meitsie, omakuva; the French - autophoto, égoportrait, and so on. ${ }^{7}$

${ }^{6}$ For information about remakes of selfie in the Swedish and Danish languages, see Strik et al., 2017, pp. 283-292. data. 
(5) selfie

Bछ Cэлфі, Selfie, cэ́nфi

CA autofoto, Selfie

HAR Sebić, Selfie

CS selfie, selfičko

(DA selfie

N1L selfie, otofoto, zelfje

EN selfie, selfie photo, selfie pic

ET selfi, Selfie

F1 selfie, meitsie, omakuva

FR selfie, autophoto, égoportrait
DE selfie

(II) selfie

LV fotopašportrets, selfijs, pašbilde

NN selfie

P2 selfie, samojebka, selfik

PT selfie, sélfie

RU cenфи, се́пфи, себя́шка

SK Selfie, svojka

St. Selfie

ES autofoto, selfi, selfie

Sv selfie, egobild, sjallvis

Fig. 1: The word selfie in the multilingual wordnet at BabelNet.org ("Selfie", n.d.).

\section{The usage of selfie in the Lithuanian language}

The first instance of usage of both the form selfie and its grammatical adaptation selfis in the Lithuanian language was recorded in 2013 at the latest. It made its first appearance in blogs, a web genre rapidly gaining in popularity in Lithuania at the time:

(1) Penktadienio selfis

Būnam madingi ir Lietuvoje su "selfie" manija. (martinavaiciunaite.wordpress.com, 2013-07-26, as cited in DN, n.d., entry selfis)

[Friday selfie

Let's be trendy in Lithuania with the "selfie" mania. $]^{8}$

(2) Tradicinis savaitès selfis šikart jau su pledu, nes DIEVINU šalț, dievinu, kai reikia nuo jo slëptis ir jaukiai suptis ị minkštus pledukus... (martinavaiciunaite.wordpress.com, 2013-09-29, as cited in DN, n.d., entry selfis)

8 The quotations from blog entries and online media texts are written in Lithuanian and presented with an English translation; the quotations in Lithuanian preserve the original spelling and punctuation; emphasis added by the author. 
[A traditional weekly selfie, this time with a blanket, because I ADORE the cold, I adore it when I have to hide from it snuggling in a bunch of soft blankets...]

Selfie was soon to pop up in the media too, and not only in the mass media targeting the youth audience, but in mainstream news portals as well:

(3) Štai naujuoju Justin Bieber tituluojamas amerikietis Austin Mahone nusprendè visas savo fanes išmokyti, kaip telefonu padaryti tokią nuotrauką, kurioje atrodytum patraukliai. "Selfie" - taip populiariai vadinama nuotrauka, kurioje jamžini save pats. Dainininkas pataria neapsimetinèti, kad nuotrauką padarei "netyčia". Pasak jo - fotografuoti "selfius" nieko blogo, tereikia išlikti savimi ir nebijoti parodyti savojo veido. (panele.lt, 2013-07-29, as cited in DN, n.d., entry selfis)

[For example, Austin Mahone from the US, who is sometimes referred to as the new Justin Bieber, has decided to teach all his lady fans how to take pictures with your phone so that you always come out hot. "Selfie" is the popular name of a picture that you take of yourself. The singer suggests you should not pretend you took the picture "by accident". According to him, there is nothing wrong with taking "selfies", all you have to do is be yourself and not be afraid to show your face.]

(4) Nauja bendra Lionelio Messi ir Kobe Bryanto reklama - kuris padarys geresni „selfie"? [antraštè] Pasaulinès sporto žvaigždès Lionelis Messi ir Kobe Bryantas nusifilmavo naujoje „Turkish Airlines“ reklamoje, kurioje abu sportininkai varžosi, kas padarys geresnę "The Selfie" vadinamą savęs paties nuotrauką. (15min.lt, 2013-12-04, as cited in DN, n.d., entry selfis)

[A new ad with Lionel Messi and Kobe Bryant: Who will take a better "selfie"? [title] World celebrity athletes Lionel Messi and Kobe Bryant are starring in the latest ad for Turkish Airlines, in which they compete who will take the best picture of himself, also known as "selfie".]

(5) Leidykla „Oxford University Press“ kasmet renka anglų kalbos metų žodị. Paprastai Jungtinėje Karalysteje ir JAV išrenkami skirtingi žodžiai, bet šiemet nugalètoju abiejose Atlanto pusèse tapo ypač išpopuliarėjęs žodis „selfie“ (selfis), skelbia „The Verge“. „Selfie“ - tai nuotraukos autoportretai, kuriomis žmonès dažnai dalinasi socialiniuose tinklalapiuose. Tokios nuotraukos dažniausiai daromos išmaniaisiais telefonais. (technologijos.lt, 2013-11-20, as cited in DN, n.d., entry selfis)

[Every year, the publishing house Oxford University Press picks the English word of the year. As a rule, different words are chosen in the United Kingdom and the US, but this year it was everyone's hot favourite "selfie" that took the crown on both sides of the Atlantic, The Verge reports. "Selfie" is a self-photograph that people usually share on social media. Such photos are often taken with smartphones.]

On the heels of selfie followed the advent to the Lithuanian language of selfie-stick: 'a stick for taking selfies that is attachable to a smartphone'. Some of its adapted forms include selfie stikas and selfistikas. 
As the loanword selfie and its grammatically adapted, inflected form selfis started to spread rapidly, the Lithuanian-speaking internet also recorded the usage of the diminutive selfiukas and other derivatives with the root self-:

(1) with reference to a person: selfininkas, $-\dot{e}$, selfukininkas, $-\dot{e}$ 'someone who takes selfies'; selfimanas, $-\dot{e}$ 'someone who is addicted to taking and uploading selfies'; ${ }^{\prime}$

(2) with reference to an act: selfintis (nusiselfinti, pasiselfinti) '(to) take a selfie';

(3) word formations: selfio (selfi) lazda 'a stick for taking selfies that can be attached to a smartphone'.

There have been several cases where the word selfie was borrowed as an international prefix and adapted as selfi-. It is added to the beginning of other words but does not become the first component of a compound, because the Lithuanian rules of word-formation require that in that case the ending of the second component would have to change. In such cases, selfi- is used just like other international prefixes, such as kiber-, kripto-, nano-, termo- and so on, for instance: selfirümai 'a palace used as a background for selfies'; selfiprotestas 'a show of protest by taking selfies'; selfisnukis vulg. 'an ugly mug in a selfie'.

Lithuanian-speaking social media contain a number of different remakes of the loanword selfie, some of them with an explanation of their semantics in terms of the Lithuanian language. For instance, there are the blends ${ }^{10}$ telfis and taufis - their author explained that a selfie (selfis) is not taken for 'yourself' (Lith. sau), but for someone else: 'you' (Lith. tau):

(6) Žmogus taip galvoja ir šitaip kalba: „Selfị aš darau ne sau. Aš darau jị, kad galěčiau parodyti kitiems. Aš darau jị tau. Selfis lietuviškai galètų vadintis ne selfis, o telfis ar taufis." (15min.lt, 2016-07-05, as cited in DN, n.d., entry selfis)

[This is what a person thinks and says: "I am not taking the selfie for myself. I am taking it so I can show it to others. I am taking it for you. In Lithuanian, rather than selfis, a selfie could be called telfis or taufis."]

The above facts show that the word selfie has attained all the typical characteristics of an adapted loanword in the Lithuanian language, and has started to become anchored in usage, as the family of its derivatives and remakes expands.

9 The word selfimanas, $-\dot{e}$ could have been coined in the Lithuanian language just as it could have been borrowed from other languages.

${ }_{10}$ This method of coining new words has seen a tremendous increase in popularity, and not just in the Lithuanian language - quite obviously, owing to the impact of English (see Cacchiani, 2016, pp. 308; Lehrer, 2007, pp. 115-136; Mattiello, 2019, pp. 1-29; Miliūnaité, 2014, pp. 246-264). 


\section{Equivalents of selfie and their derivatives in the Lithuanian language}

Like many other European languages, the Lithuanian language, too, leans towards purity and is inclined to replace loanwords with own words, whenever possible. ${ }^{11} \mathrm{It}$ is therefore natural that the usage has seen an influx of Lithuanian equivalents of selfie.

\subsection{Asmenuke}

Lithuanian equivalent of selfie number one, the neologism asmenuke was first found in use online (on social media) in early 2014. It is a derivative of the noun asmuo 'person' with the suffix -uke.

Naturally, new, unusual words are not always well received by language users straight away. The very same discussion thread featured a comment in which asme$n u k \dot{e}$ was criticised for the unwelcome association with the personal ID card that it brings to mind, and pačiukas was offered as an alternative:

(7) Lai SELFIE tampa ASMENUKĖMIS! Garbẻ šiai madai, tokių intymių kadrų jokiam paparacui niekuomet nepavyktų užfiksuoti! (facebook.com, 2014-01-09, as cited in DN, n.d., entry selfis)

[Let SELFIE become ASMENUKE்! Promote this trend, no paparazzi could ever take such intimate shots!]

(8) gal tada geriau pavadinti "pačiuku"? asmenuke man skamba kaip kokia asmens tapatybes kortele. (facebook.com, 2014-01-09, as cited in DN, n.d., entry selfis)

[could we at least rename it "pačiukas"? to me, asmenukè sounds a bit like some ID card.]

At the same time, the selfie culture as such took social media by storm, creating fertile ground in which words related to it could spread among users like wildfire. ${ }^{12}$ The official consultations bank of the State Commission of the Lithuanian Language (SCLL, n.d.) also recommends using the Lithuanian variant asmenuke instead of the word selfie.

${ }^{11}$ This trend is sometimes erroneously considered to be identical to purism. As used here, purity (the purification of language) is not viewed as something negative, but as a phenomenon typical of certain speech communities that usually do not have a lot of speakers and seek to preserve the authenticity of language and often promote their own means of expression via language policies.

12 Another factor behind the rapid spread of the use of asmenuke might have been a radio interview whose account was published on one of the popular online news portals (see Lietuviu kalbos naujadarai, 2014). 


\subsection{Asmenute, asmeninuke}

The media soon served two similar neologisms that shared the same root: asmenute, a derivative of the noun asmuo (gen. sing. asmens) 'person' with the suffix -uté; and asmeninuke, a derivative of the adjective asmeninis 'personal' with the suffix -uke. When it comes to usage, they posed competition to asmenuke, yet the competition was not very clear, because asmenuke soon became the dominant variant.

\subsection{Derivatives of the Lithuanian equivalents}

The underlying word asmenuke was taken as a basis for derivatives to name actors and the act.

The actor who takes selfies was named using the neologism asmenukininkas, $-\dot{e}$, which came into competition with selfininkas, $-\dot{e}$ and selfukininkas, $-\dot{e}$, derivatives with a borrowed root. In addition to selfintis, the Lithuanian equivalent asmenukintis soon appeared to describe the act of taking selfies.

The loanword selfistikas and the hybrid selfio (selfi) lazda got their Lithuanian equivalent asmenuklazde and its abridged version - asmenlazde. The latter neologism is based on asmuo 'person' rather than asmenuke as its first component.

Interestingly, just like selfie in the English language, the Lithuanian asmenuke became a formational model on which the denomination of its other types would be based. Cases recorded in usage that contain the suffix -uke include grupinuke ('a group selfie taken by a group of people', Eng. wefie), gyvūnuke ('a selfie with a pet', Eng. petfie), and droninuke ('a selfie taken with a mobile phone from a drone'). No adapted English loanwords ${ }^{*}$ dronis, ${ }^{*}$ petfis or ${ }^{*}$ vyfis have been discovered, and for an obvious reason: these words lack semantic transparency in the Lithuanian language, and they do not conjure any associations (except perhaps for ${ }^{\star} d r o n i s$, but in Lithuanian it would probably connect with the word dronas 'unmanned aircraft' rather than a selfie taken that way). So, the link of borrowing these words has been skipped and the underlying English words were translated into Lithuanian right away, and then adapted to asmenuke.

The expanding family of the neologism, where the underlying word is tied to the Lithuanian root asmen-, shows that basically all known derivatives and remakes of selfie have been covered with their Lithuanian equivalents. This makes the utility of the Lithuanian equivalent asmenuke for making new derivatives a key reason behind the anchorage of the word. 


\section{The framework of competing variants and their stylistic differentiation}

Naturally, variants that compete in usage can eventually gain a variety of stylistic and functional qualities. In language that is not subject to any proofreading (such as on social media), the loanword selfis (and its raw form selfie) is still quite a common occurrence. In the media and in texts authored by journalists as such (as compared to interviews), asmenuke takes the predominant position..$^{13}$ Therefore, for now, these two competing options tend to follow a distribution pattern based on the formalinformal style scale. Social media comments sometimes feature opinions that asme$n u k e$ is an artificial word made by linguists, while selfis is the preferred option for colloquial use. The raw form selfie is rather indicative of the author's desire to appear hip, and sometimes of his or her linguistic negligence, because the non-inflectional form used in a sentence is clearly perceived as foreign and lacking any adaptation to the rules of the Lithuanian grammar.

However, it has to be noted that this stylistic-functional differentiation between the loanword and the Lithuanian equivalent is very fluid, for the more time passes, the more ordinary (neutral) the word asmenuke becomes, its novel and artificial character losing its flair, its usage most likely set to expand. The word asmenuke has been included in the new digital Dictionary of the Standard Lithuanian Language (DSLL) under development.

Another interesting neologism that has been recorded on social media - this one made up as a joke - is the compound word savipliauskis, forged from the pronoun sau (sav-) 'self-' and the root of the rather colloquial verb pliauškinti '(to) take pictures'. It carries a clear stylistic connotation and is a one-off derivative in itself.

Arranged in a structured order, the families of derivatives and the semantic ties of the loanword selfie (selfis) and its Lithuanian equivalent asmenuke show that two contesting systems have emerged in the Lithuanian language over the period between 2013 and this day (see Fig. 2).

This indicates the ability of the Lithuanian language to successfully adapt new cultural phenomena and their names. At the same time, one can see vigorous efforts by language users to take advantage of the different means of expression of the Lithuanian language to denominate a new phenomenon.

${ }^{13}$ New entries are being added to the DN all the time and they stand to show that there have been several more isolated and situational synonyms to selfis/asmenuke recorded in usage. Analysing them all would require a separate study. 


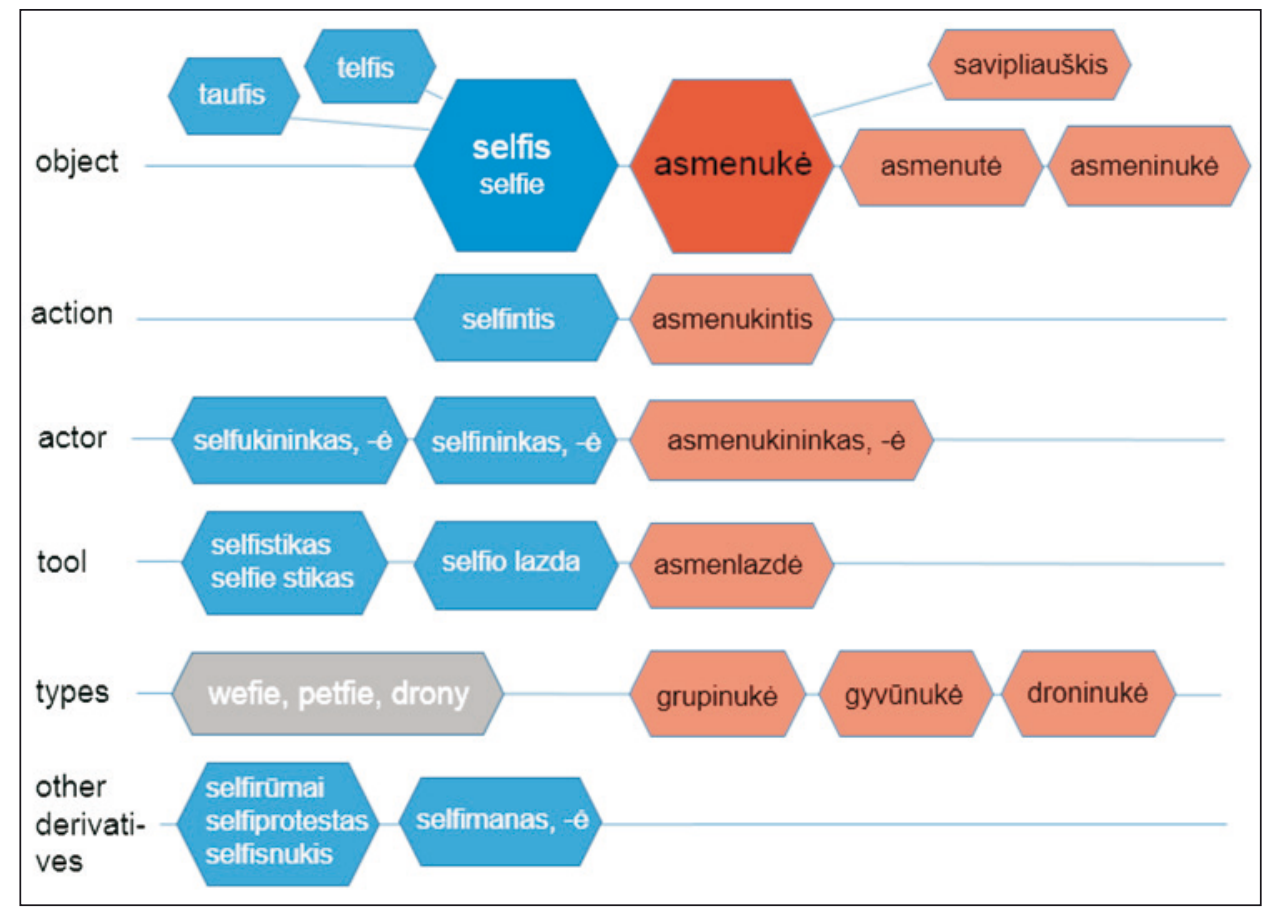

Fig. 2: The competition between the families of the neologisms selfis and asmenuke and the semantic ties of their derivatives.

\section{Conclusions}

In the early twenty-first century, electronic communication saw the emergence of a new sociocultural phenomenon - taking self-photos and publishing them on social media, which soon became quite popular. It was called the selfie and this neologism and its variants started to spread in line with the underlying phenomenon. After it made its way to other languages, this word and its semantic and formational family would become rooted there just as it would promote the development of its equivalents in the host language.

The story behind the origins of the neologism selfie in the (Australian) English language in 2002 was not a very typical one, but the cause was much the same as with many other neologisms: the need to name a new reality. The appearance of selfie's equivalents in other languages, especially those that are defined by a purist approach to borrowed lexis, has been driven by both the nominative and the purifying function. 
The social media as a conduit for all sorts of cultural and linguistic innovations was basically the reason why the word selfie was so quick in its passage through the main and typical phases for neologisms to socialise and lexicalise in both the English and Lithuanian languages. The neologism thus created spread across the social media and then made a jump to other media and the whole of the speech community. It was entered in the major dictionaries of the English language and was named the Word of the Year in 2013. Derivatives and remakes of the word selfie have emerged to spread across other languages.

The neologism selfie entered the Lithuanian language on the heels of a new reality and had made its appearance by the year 2013. It soon attained all of the properties (i.e. got its own ending and could be inflected) typical of its adapted loanword (selfis) and became anchored in usage. As the family of derivatives and remakes based on the root self-grew, some Lithuanian equivalents emerged. The most popular of them was asmenuke, which was first recorded on social media in early 2014 at the latest. The family of its derivatives and remakes has also grown with the passage of time, both as a result of the frequency of the word's usage and its formational potential.

There are two rival semantic formational families that have taken shape in the Lithuanian language. One of them is the loanword selfie (selfis) and derivatives based on its root (selfintis, selfukininkas, and so on). The second family of words consists of the equivalents of this word (usually based on the stem asmen-) and their derivatives (asmenukintis, asmenlazde, and so on). Usage reflects a tendency for differentiating these families on the basis of the formal-informal style scale. In private usage, the competition between selfis and asmenuke is more fierce, but the mainstream media have basically adopted the purely Lithuanian variant. More specific conclusions regarding the nature of the competition (including variation within the same text) could be made following a thorough analysis of usage data that would allow highlighting various linguistic and extra-linguistic factors, such as semantic clarity of neologism, its possibility to make new derivatives, the frequency of usage, usage styles and registers, the role of codification and authority figures (the media and influencers).

The case of selfie, which appeared in the English language and has then spread across other languages, is but one of many examples of intercultural and inter-language interaction. A larger number of comparative neological studies of other languages would be required to form a better understanding of the origin, functioning, and prevalence of neologisms, as well as the mechanisms of how local equivalents of borrowings are made and how they compete with them. 


\section{Abbreviations}

DN - Database of Lithuanian Neologisms (Lith. Lietuviu kalbos naujažodžiu duomenynas) (n.d.). Retrieved May 5-30, 2021, from https://ekalba.lt/naujazodziai/

DSLL - Dictionary of the Standard Lithuanian Language (Lith. Bendrines lietuviu kalbos žodynas). (n.d.). Retrieved May 16, 2021, from https://ekalba.lki.lt/bendrines-lietuviu-kalbos-zodynas

MD-p - Macmillan Dictionary. (n.d.). Protologism. In Macmillan Dictionary.com. Retrieved May 16, 2021, from https://www.macmillandictionary.com/dictionary/british/protologism

MD-s - Macmillan Dictionary. (n.d.). Selfie. In Macmillan Dictionary.com. Retrieved May 5, 2021, from https://www.macmillandictionary.com/dictionary/british/selfie

MW - Merriam-Webster. (n.d.). Selfie. In Merriam-Webster.com Dictionary. Retrieved May 5, 2021, from https://www.merriam-webster.com/dictionary/selfie

OED - Oxford English Dictionary. (n.d.). Selfie. In Oxford English Dictionary. Retrieved May 5, 2021, from https://www.oed.com/view/Entry/390063

SCLL - State Commission of the Lithuanian Language. The Bank of Consultations. (Lith. Valstybine lietuviu kalbos komisija. Konsultaciju bankas). (n.d.). Asmenuke, selfis, selfie. In The Bank of Consultations. Retrieved May 20, 2021 from http://www.vlkk.lt/konsultacijos/ 11470-asmenuke-selfie

UD - Urban Dictionary. (n.d.). Selfie. In Urban Dictionary.com. Retrieved May 9, 2021, from https://www.urbandictionary.com/define.php?term=Selfie

\section{Dictionaries}

Bendrinès lietuvių kalbos žodynas [DSLL]. (n.d.). Retrieved May 16, 2021, from https://ekalba. lki.lt/bendrines-lietuviu-kalbos-zodynas

Lietuviu kalbos naujažodžių duomenynas [DN]. (n.d.). Retrieved May 5-30, 2021, from https:// ekalba.lt/naujazodziai/

Merriam-Webster [MW]. (n.d.). Selfie. In Merriam-Webster.com dictionary. Retrieved May 5, 2021, from https://www.merriam-webster.com/dictionary/selfie

Protologism [MD-p]. (n.d.). In Macmillan dictionary.com. Retrieved May 16, 2021, from https://www.macmillandictionary.com/dictionary/british/protologism

Selfie [MD-s]. (n.d.). In Macmillan dictionary.com. Retrieved May 5, 2021, from https://www. macmillandictionary.com/dictionary/british/selfie

Selfie [OED]. (n.d.). In Oxford English dictionary. Retrieved May 5, 2021, from https://www.oed. $\mathrm{com} /$ view/Entry/390063

Selfie [UD]. (n.d.). In Urban dictionary.com. Retrieved May 9, 2021, from https://www.urbandictionary.com/define.php?term=Selfie

Valstybinè lietuvių kalbos komisija. [SCLL]. (n.d.). Asmenukè, selfis, selfie. In Konsultacijų bankas. Retrieved May 20, 2021, from http://www.vlkk.lt/konsultacijos/11470-asmenuke-selfie 


\section{Bibliography}

Belfie, drelfie, helfie, and more variations on selfie. (2015, January 9). The Week. https://theweek.com/articles/447231/belfie-drelfie-helfie-more-variations-selfie

Brumfield, B. (2013, November 20). Selfie named word of the year for 2013. CNN. https://edition. cnn.com/2013/11/19/living/selfie-word-of-the-year/index.html

Cacchiani, S. (2016). On Italian lexical blends: Borrowings, hybridity, adaptations, and native word formations. In S. Knospe, A. Onysko, \& M. Goth (Eds.), Crossing languages to play with words: Multidisciplinary perspectives (Vol. 3, pp. 305-335). De Gruyter. https://doi. org/10.1515/9783110465600-015

Coulthard, C. (2013, June 7). Self-portraits and social media: The rise of the 'selfie'. BBC. http:// www.bbc.com/news/magazine-22511650

Eckel, J., Ruchatz, J., \& Wirth, S. (2018). The selfie as image (and) practice: Approaching digital self-photography. In J. Eckel, J. Ruchatz, \& S. Wirth (Eds.), Exploring the selfie: Historical, theoretical, and analytical approaches to digital self-photography (pp. 1-24). Palgrave Macmillan. https://doi.org/10.1007/978-3-319-57949-8

Fjeld, R. V., \& Nygaard, L. (2012). Lexical neography in modern Norwegian. In G. Andersen (Ed.), Exploring newspaper language: Using the web to create and investigate a large corpus of modern Norwegian (pp. 221-240). John Benjamins Publishing Company. https://doi. org/10.1075/scl.49.10fje

Hanaqtah, M. (2019). Translation of political neologisms coined by politicians: Issues and strategies. Journal of Social Sciences (COES\&RJ-JSS), 8(1), 157-168. https://doi.org/10.25255/ jss.2019.8.1.157.168

Hjarvard, S. (2013). The mediatization of culture and society. Routledge. https://doi. org/10.4324/9780203155363

Humbley, J. (2018). Term formation and neology. In J. Humbley, G. Budin, \& C. Laurén (Eds.), Languages for special purposes (pp. 437-452). De Gruyter Mouton. https://doi. org/10.1515/9783110228014-022

Kerremans, D. (2015). A web of new words: A corpus-based study of the conventionalization process of English neologisms. Lang. https://doi.org/10.1515/east-2016-0007

Lehrer, A. (2007). Blendalicious. In J. Munat (Ed.), Lexical creativity, texts and contexts (pp. 115-136). John Benjamins Publishing Company. https://doi.org/10.1075/sfsl.58.16leh

Lietuviu kalbos naujadarai: Kaip atsirado "düzgès" ir "asmenukë"? (2014, March 21). https:// www.15min.lt/naujiena/aktualu/lietuva/lietuviu-kalbos-naujadarai-kaip-atsirado-duzges-ir-asmenuke-56-414004?cf=df

Mattiello, E. (2017). Analogy in word-formation: A study of English neologisms and occasionalisms. De Gruyter Mouton. https://doi.org/10.1515/9783110551419

Mattiello, E. (2019). A corpus-based analysis of new English blends. Lexis, 2019(14), 1-29. https://doi.org/10.4000/lexis.3660 
Miliūnaitè, R. (2014). Naujieji kontaminaciniai dariniai lietuvių kalboje. Acta linguistica Lithuanica, 2014(71), 246-264. http://journals.lki.lt/actalinguisticalithuanica/article/ view/930/1020

Miliūnaitė, R. (2018). Naujažodžių pateikimas ir paieškos galimybès Lietuvių kalbos naujažodžių duomenyne. Bendrine kalba, 2018(91), 1-21. http://www.bendrinekalba.lt/Straipsniai/91/Miliunaite_BK_91_straipsnis.pdf

Parianou, A., \& Kelandrias, P. (2002). Special terms: Conditions and requirements for their creation and development. Proceedings of the International Conference Translating in the 21st century: Trends and prospects, 27-29 September 2002 (pp. 214-228). Aristoteleio University of Thessaloniki, Faculty of Arts.

Sandbye M. (2018) Sandbye, M. (2018). Selfies and purikura as affective, aesthetic labor. In J. Eckel, J. Ruchatz, \& S. Wirth (Eds.), Exploring the selfie: Historical, theoretical, and analytical approaches to digital self-photography (pp. 305-326). Palgrave Macmillan https://doi.org/10.1007/978-3-319-57949-8_14

Selfie. (n.d.). In A Wide-Coverage Multilingual Semantic Network BabelNet 4.0. Retrieved April 4, 2020, from http://live.babelnet.org

Strik, O., Norde, M., \& Beijering, K. (2017). On blended selfies and tainted smoothies. In M. Wieling, M. Kroon, van G. Noord, \& G. Bouma (Eds.), From semantics to dialectometry: Festschrift in honor of John Nerbonne (pp. 283-292). University of Groningen.

WebCorp Linguist's Search Engine. (n.d.). Retrieved May 5-25, 2021, from http://www.webcorp. org.uk/live/

Zabotkina, V. (1989). Novaia leksika sovremennogo angliǔskogo iazyka. Vysshaia shkola. https:// classes.ru/grammar/138.Zabotkina/worddocuments/_htm

\title{
New Lexis in the Interaction of Languages and Cultures: The Case of Selfie in the Lithuanian Language
}

\begin{abstract}
This article deals with the adaptation of the English neologism selfie in the Lithuanian language. It sheds light on how selfie first appeared in Australian English back in 2002 and on the socialisation and lexicalisation of this word in the English and Lithuanian languages. The aim here is to analyse the characteristics of the usage of the neologism selfie and its adapted form selfis in the Lithuanian language as well as its rivalry with other Lithuanian equivalents of the word.

Based on the usage data obtained from the Database of Lithuanian Neologisms, the online corpus WebCorp, and the Google search engine, the loanword selfie was found to have first appeared in Lithuanian blogs back in 2013 at the latest. After a brief period of time, in early 2014 or sooner, it began vying with its Lithuanian equivalent, asmenuke. Eventually, with the formational families of selfis and asme-
\end{abstract}


nuke expanding, two rival lexical semantic systems have emerged in the Lithuanian language, both consisting of what usually are variations of the name of the object (selfie, selfis and asmenuke, asmenuté, asmeninuke), actor (selfininkas, - $\dot{e}$, selfukininkas, $-\dot{e}$ and asmenukininkas, $-\dot{e}$ ), action (selfintis and asmenukintis), and additional tool (selfi stikas, selfio lazda and asmenuklazdè), as well as the different new versions thereof.

After it had made its way into the Lithuanian language, the English neologism selfie (selfis), as the name for a new sociocultural phenomenon with its own semantic and formational family, became anchored there and was adapted to the inflectional system of the host language just as it provided an impetus for producing local equivalents. This case can be considered to be a typical mini-model, one that demonstrates what happens when a loanword for a new and trendy element of reality, which therefore has a considerable potential to spread, enters the Lithuanian language. Without a shadow of doubt, similar processes are also taking place in other languages that have borrowed this word. New comparative neological studies of other languages would help us form a better understanding of the origin, functioning, and prevalence of neologisms, as well as the mechanisms of how local equivalents of borrowings are made and how they compete with them.

Keywords: neology; neologisms; borrowings; derivatives; language contact; social network

\section{Nowa leksyka w interakcji języków i kultur: przypadek selfie w języku litewskim}

\section{Streszczenie}

Niniejszy artykuł jest poświęcony adaptacji angielskiego neologizmu selfie w języku litewskim. Rzuca światło na to, jak słowo selfie pojawiło się po raz pierwszy w australijskiej odmianie języka angielskiego w 2002 roku oraz na jego socjalizację i leksykalizację w języku angielskim i języku litewskim. Opracowanie ma na celu analizę cech użycia neologizmu selfie i zaadaptowanej formy selfis w języku litewskim oraz jego rywalizacji z innymi litewskimi odpowiednikami.

Na podstawie informacji z Bazy Danych Litewskich Neologizmów, internetowego korpusu WebCorp i wyszukiwarki Google, stwierdzono, że zapożyczenie selfie pojawiło się po raz pierwszy na litewskich blogach najpóźniej w 2013 roku. Wkrótce, na początku 2014 roku lub wcześniej, zaczęło rywalizować ze swoim litewskim odpowiednikiem: asmenukè. Ostatecznie, wraz z rozwojem rodzin wyrazów selfis i asmenuke, w języku litewskim pojawiły się dwa rywalizujące ze sobą leksykalne sys- 
temy semantyczne, składające się z odmian nazwy obiektu (selfie, selfis i asmenuke, asmenute, asmeninuké), aktora (selfininkas, $-\dot{e}$, selfukininkas, $-\dot{e}$ i asmenukininkas, $-\dot{e}$ ), czynności (selfintis i asmenukintis) i dodatkowego narzędzia (selfi stikas, selfio lazda i asmenuklazde) oraz rozmaitych nowych wersji tych nazw.

Po przejściu do języka litewskiego, angielski neologizm selfie (selfis), jako nazwa nowego zjawiska społeczno-kulturowego $\mathrm{z}$ własną rodziną semantyczną i słowotwórczą, został w nim zakotwiczony i dostosowany do rodzimego systemu fleksyjnego i dał impuls do tworzenia lokalnych odpowiedników. Ten przypadek można w pewnym sensie uznać za modelowy, pokazuje bowiem, co się dzieje, gdy zapożyczenie nazwy na określenie nowego i bardzo modnego elementu rzeczywistości, który ma zatem znaczny potencjał rozprzestrzeniania się, wchodzi do języka litewskiego. Podobne procesy bez wątpienia zachodzą również w innych językach, które zapożyczyły to słowo. Podjęcie nowych badań porównawczych pomogłoby lepiej zrozumieć powstawanie, funkcjonowanie i rozpowszechnianie się neologizmów, a także mechanizmy tworzenia rodzimych odpowiedników i ich konkurowania z zapożyczeniami.

Słowa kluczowe: neologia; neologizmy; zapożyczenia; kontakt językowy; sieć społecznościowa

Dr Rita Miliūnaitė, Chief Researcher at the Institute of the Lithuanian Language, Vilnius; PhD thesis - 1992, Vilnius University; habilitation procedure - 2009, Vytautas Magnus University, Kaunas. Author of five books, about fifty scholarly articles, co-author of a usage guide to the Lithuanian language, co-author of the Database of Lithuanian Neologisms, author of four educational computer games. Her scholarly interests include sociolinguistics, language planning and language policy, neology, language technologies.

Bibliography (selected): Lietuviu kalbos gramatikos norminimo pagrindai [The foundations of the standardization of Lithuanian grammar], Vilnius 2003; Apie kalba ir mus [About language and us], Vilnius 2006; Dabartines lietuviu kalbos vartosenos variantai [Variants of current Lithuanian language usage], Vilnius 2009; Ka manote apie nepriesagines motery pavardes? [What do you think about non-suffixed female surnames?], Vilnius 2013; Kalbos normos ir jų savireguliacija interneto bendruomené$j e$ [Language norms and their self-regulation in the internet community], Vilnius 2018. 
Correspondence: Rita Miliūnaite, Institute of the Lithuanian Language, Vilnius, e-mail: rita.miliunaite@lki.lt

Support of the work: This work was supported by core funding for the statutory activity of the Institute of the Lithuanian Language.

Competing interests: The author declares that she has no competing interests.

Publication History: Received: 2021-06-14; Accepted: 2021-09-28; Published: 2021$12-21$. 